\title{
Trophoblastic and decidual response to RU486: effects on human chorionic gonadotrophin, human placental lactogen, prolactin and pregnancy-associated plasma protein-A production in vitro
}

\author{
P.Bischof ${ }^{1}$, M.T.Sizonenko and W.L.Herrmann \\ Division of Biology of Growth and Reproduction, Department of Obstetrics \\ and Gynecology, University of Geneva, Switzerland \\ 'Present address: Laboratoire d'hormonologie, Maternité, $\mathrm{CH}-1211$ Genève \\ 4. Switzerland
}

RU486 [17 $\beta$-hydroxy-11 $\beta$-(4-dimethylaminophenyl)-17 $\alpha$ (prop-1-ynyl)-oestra-4,9-dien-3-one] a potent progesterone antagonist, was shown to induce abortions in humans. Human chorionic gonadotrophin (HCG) and pregnancy-associated plasma protein-A (PAPP-A) decreased after RU486 administration, but it was not clear whether these effects were due to RU486 or secondary to trophoblast damage. To answer this question we tested the in-vitro effects of RU486 on shortterm cultures of trophoblastic and decidual explants. It was observed that RU486 induced a significant inhibition of the trophoblastic production rate of $\beta$ HCG and PAPP-A but not human placental lactogen. This effect could be overcome by addition of progesterone (for PAPP-A and $\beta$ HCG) or cortisol (for $\beta$ HCG). Decidual prolactin (Prl) or PAPP-A secretions were also inhibited by RU486. Progesterone antagonized these effects, whereas cortisol was ineffective. These results suggest that PAPP-A is a progesterone-dependent protein and that the abortifacient effect of RU486 in humans could at least partially be due to an inhibition of the production of HCG and/or PAPP-A.

\section{Introduction}

RU486 [17 $\beta$-hydroxy-11 $\beta$-(4-dimethylaminophenyl)-17 $\alpha$-(prop1 -ynyl)-oestra-4,9-dien-3-one] is a potent progesterone antagonist with no agonistic activity (Philibert $e t$ al., 1982), but with demonstrable anti-glucocorticoid activity (Gaillard et al., 1984). RU486 induces menses in primates (Healy et al., 1983) and was tested as an abortifacient in humans (Herrmann et al., 1982). In this last study nine out of 11 women aborted after RU486 treatment (200 mg daily for 4 days). Gonadotrophin and steroid hormone levels (Hermann et al., 1985) as well as pregnancy-associated plasma protein-A (PAPP-A) concentrations (Bischof et al., 1985) were studied in these women. It was observed that maternal levels of chorionic gonadotrophin ( $\beta$ HCG) and PAPP-A decreased in RU486-induced abortions, but it could not be determined if this decrease was induced by RU486 or if it was secondary to trophoblast damage. In order to find an answer to this question and to gain some insight into the mechanism whereby RU486 induces abortions, we investigated the in-vitro effects of this progesterone antagonist on trophoblastic and decidual explant cultures.

\footnotetext{
Materials and methods

RU486 was a gift from Roussel-Uclaf (France), progesterone and cortisol from Sigma (Calbiochem, Lucerne, Switzerland). Steroid solutions were prepared in dimethyl sulphoxide (DMSO), stored at $4^{\circ} \mathrm{C}$ and added to the culture media after final sterilizatron. Blood was obtained from third trimester pregnant volunteers. After clotting, the sera were pooled, stored at $-20^{\circ} \mathrm{C}$ and added to the culture media $(10 \%)$ when required [referred to hereafter as pregnancy serum (PS)].
}

Trophoblast and decidua were obtained from 10 patients undergoing surgical termination of pregnancy ( $7-12$ weeks) Tissues were brought to the laboratory withın $5 \mathrm{~min}$ after dilatation and curettage, prepared and cultured as reported previously (Bischof et al., 1984a). Trophoblast and decidua were cultured in duplicates for $8 \mathrm{~h}$ (w1th one change after $4 \mathrm{~h}$ ) in medium 199 (Gibco, Basel, Switzerland) supplemented with $5 \%$ fetal calf serum. After these initial $8 \mathrm{~h}$, the culture media were changed: one group of tussues was left to incubate in modium 199 alone, whereas five ather groups were incubated in medium 199 supplemented, respectively, with RU486 $(100 \mathrm{ng} / \mathrm{ml})$, progesterone $(500 \mathrm{ng} / \mathrm{ml})$, cortisol $(500 \mathrm{ng} / \mathrm{ml})$, PS $(10 \%)$ and a combination of these. Media were changed once again after $24 \mathrm{~h}$ of culture. At the end of the culture period ( $48 \mathrm{~h}$ ), tussues were harvested, weighed and homogenized in $2 \mathrm{ml}$ of culture media.

Prolactin (Prl), human placental lactogen (HPL) and $\beta$ HCG were measured In media and tissue homogenates using commercially available kits (CIS-IRE, Medipro, Teufen, Switzerland). PAPP-A was measured in the same samples by a solid phase second antibody radioimmunoassay as described elsewhere (Bischof et al. 1981).

The results were expressed as production rates and calculated as follows: concentrations of each protein as measured in the medrum after 24 and $48 \mathrm{~h}$ of culture were added and divided by the wet weight of the tissue and by the number of hours the tissue was in contact with the specific medium $(\mu \mathrm{g} / \mathrm{g} / 40 \mathrm{~h})$. Statistical evaluation was done by the $\mathrm{t}$-test for unpaired variables.

Results

\section{Trophoblast}

$H P L$. Irrespective of the composition of the incubation medium, neither the tissue concentration of HPL nor its production rate

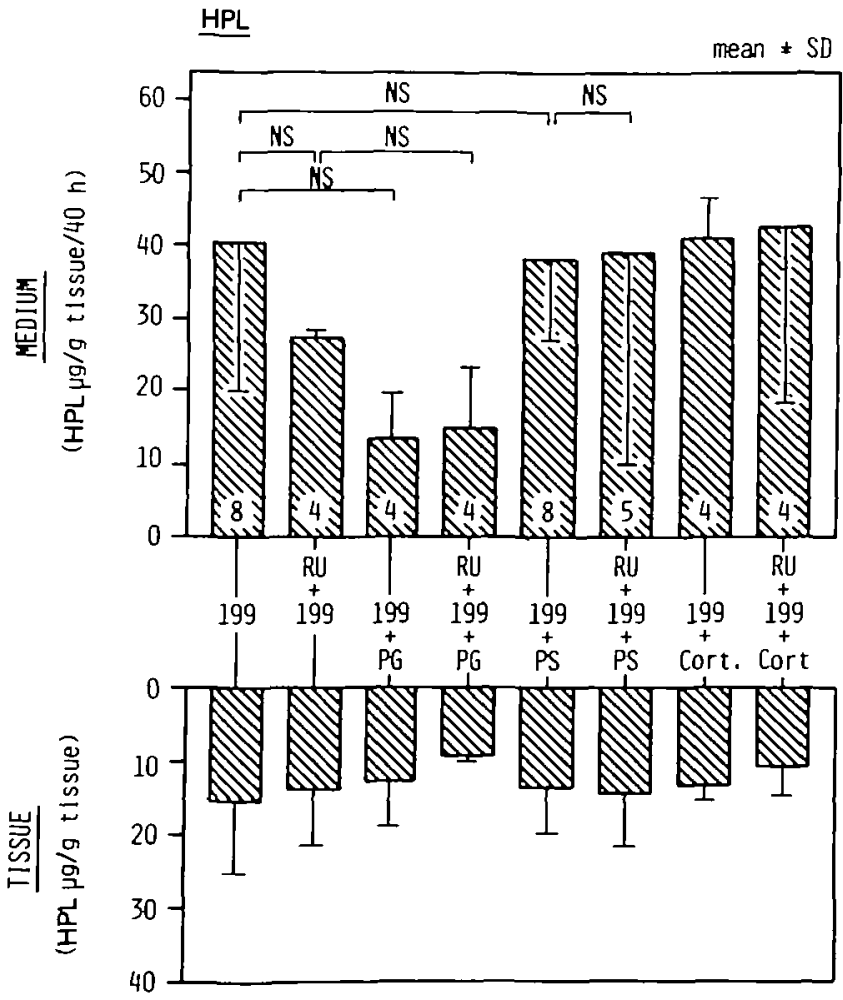

Fig. 1. Trophoblastic production rate and tissue concentration of HPL, RU (RU486), PG (progesterone), PS (pooled maternal pregnancy serum), Cort (contisol), 199 (medium 199 from Gibco). Numbers within the bars indicate the number of experiments run in duplicate. 


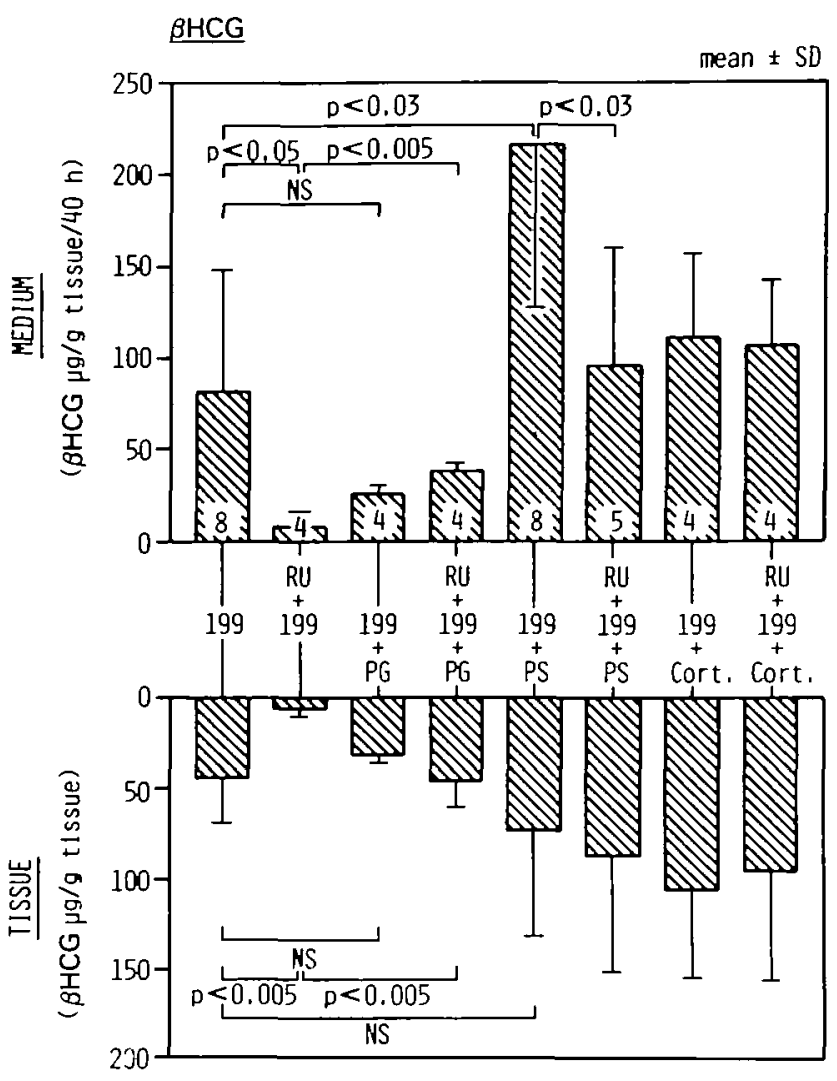

Fig. 2. Trophoblastic production rate and tissue concentration of $\beta \mathrm{HCG}$ (abbreviations as Figure 1).

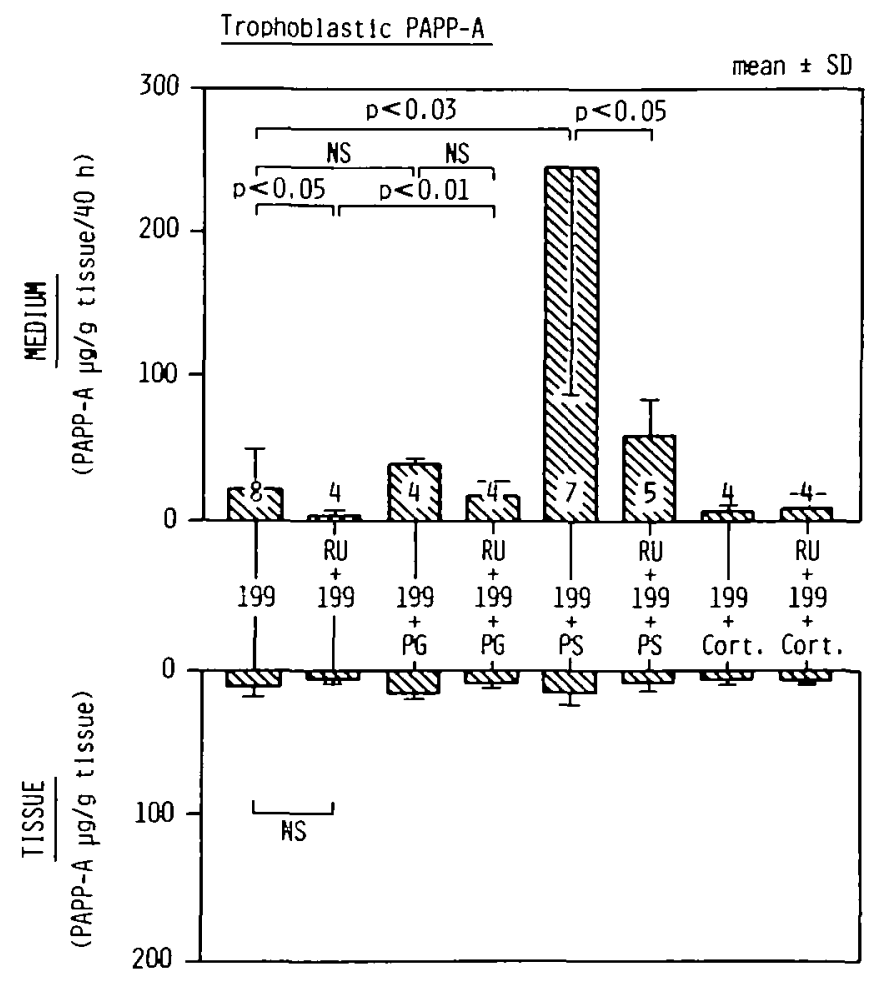

Fig. 3. Trophoblastic production rate and tissue concentration of PAPP-A (abbreviations as Figure 1).

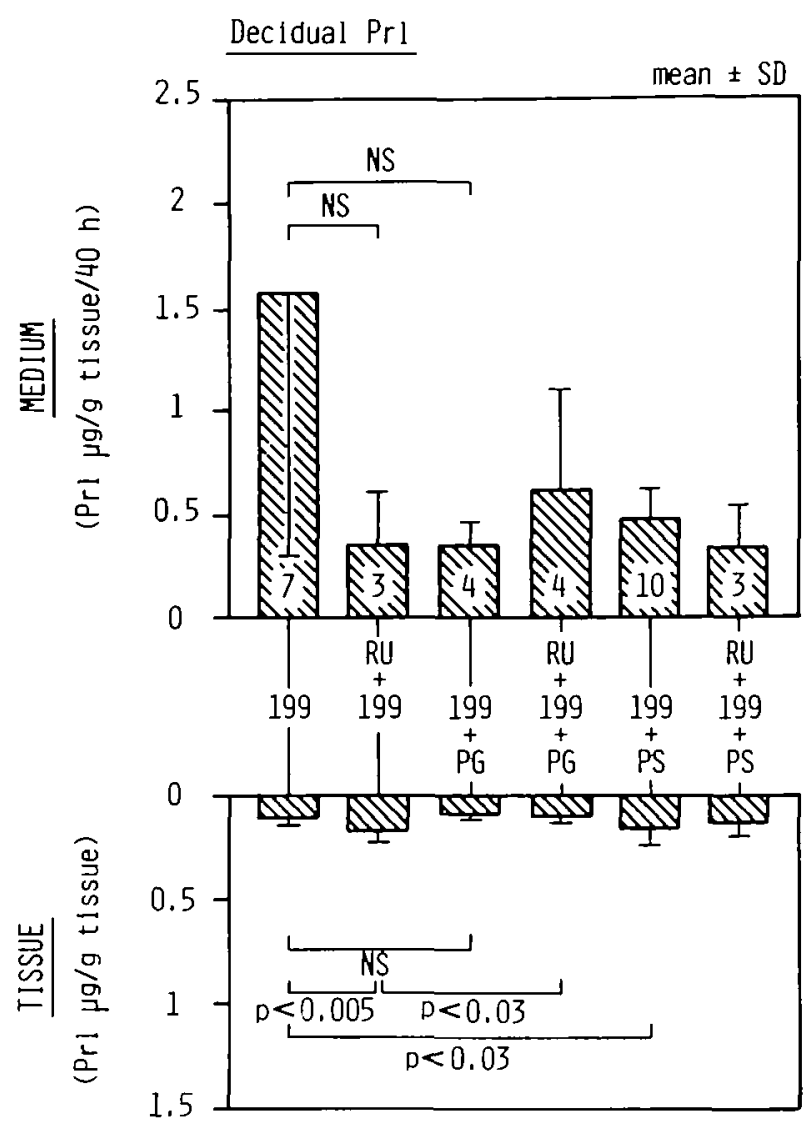

Fig. 4. Decidual production rate and tissue concentration of $\mathrm{Prl}$ (abbreviations as Figure 1).

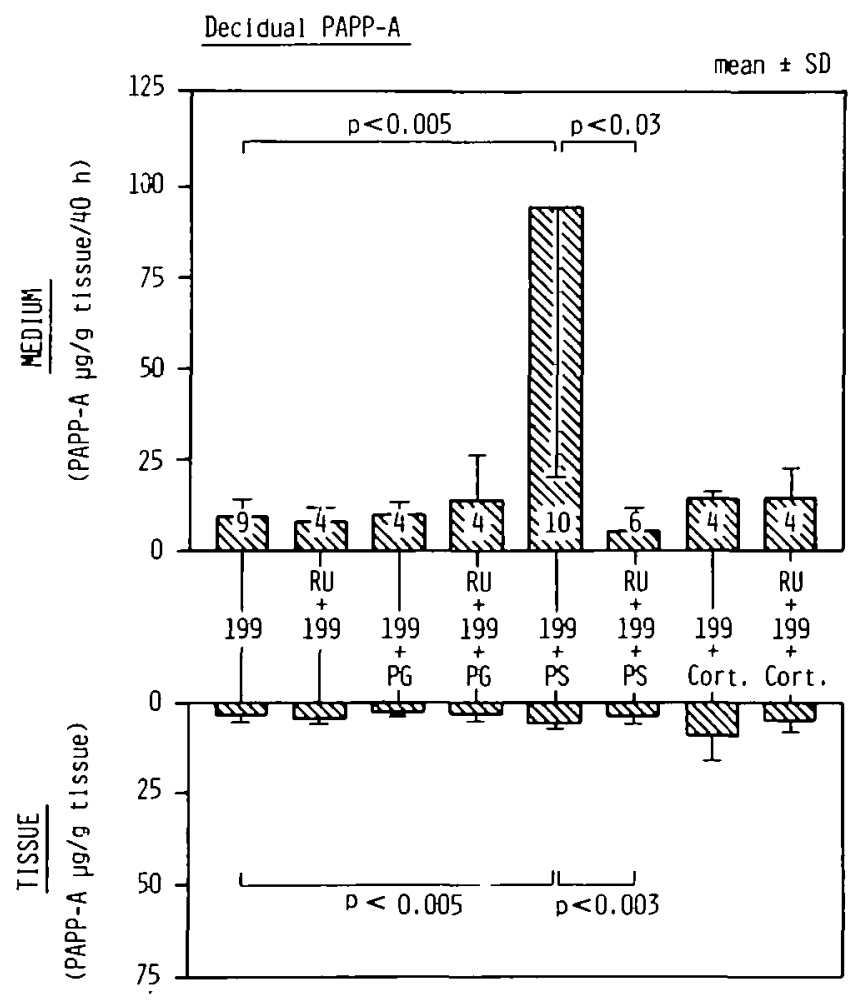

Fig. 5. Decidual production rate and tissue concentration of PAPP-A (abbreviations as Figure 1) 
were significantly changed (Figure 1).

$\beta H C G$. RU486 induced a significant $(p<0.05)$ decrease in the production rate and in the tissue concentration $(p<0.005)$ of $\beta \mathrm{HCG}$ as compared with control media (Figure 2). These effects could be reversed by the addition of $500 \mathrm{ng} / \mathrm{ml}$ progesterone and cortisol whereas neither progesterone nor cortisol alone had a significant effect. The addition of PS to the incubation medium significantly increased the production rate of $\beta \mathrm{HCG}$ over control medium $(p<0.03)$. The addition of RU486 $(100 \mathrm{ng} / \mathrm{ml})$ to PSsupplemented media induced a significant $(p<0.03)$ decrease of $\beta \mathrm{HCG}$ as compared with PS alone (Figure 2).

$P A P P-A$. The tissue concentration of PAPP-A did not change significantly irrespective of the composition of the incubation media. The secretion rate of PAPP-A, however, was significantly $(p<0.05)$ inhibited by RU486 $(100 \mathrm{ng} / \mathrm{ml})$ as compared with anti-progesterone-free media (Figure 3). Progesterone $(500 \mathrm{ng} / \mathrm{ml})$ but not cortisol $(500 \mathrm{ng} / \mathrm{ml})$ did reverse this inhibitory effect whereas progesterone or cortisol alone did not alter PAPP-A production. As for $\beta \mathrm{HCG}$, media supplemented with PS significantly $(p<0.03)$ increased the production rate of PAPP-A as compared with control media, whereas RU486 significantly $(p<0.05)$ antagonized this effect (Figure 3 ).

\section{Decidua}

Prl. The production rate of Prl was similar in the different incubation media, but the tissue concentration of Prl was significantly $(p<0.05)$ increased over controls by RU486 $(100 \mathrm{ng} / \mathrm{ml})$. This effect could be reversed by the addition of progesterone (Figure 4). PS-supplemented media induced a significant increase in $\mathrm{Prl}$ tissue concentration when compared with controls $(p<0.03)$, but RU486 could not reverse this effect (Figure 4).

$P A P P-A$. PS-supplemented media significantly increased the production rate $(p<0.005)$ and the tissue concentration $(p<0.005)$ of PAPP-A. Both effects could be reversed by RU486 (Figure 5). In all other media, the production rate of PAPP-A remained similar to controls.

\section{Discussion}

It is well-documented that the decidua produces Prl (Riddick and Kusmik, 1977; de Ziegler and Gurpide, 1982) and that this production can be stimulated by progesterone (Daly et al., 1983). The present data show that RU486 increases the concentration of Prl in decidual tissue, suggesting that this potent progesterone antagonist interferes with the secretion rather than the production of Prl. However, under our experimental conditions, progesterone did not stimulate the production of Prl, whereas it did antagonize the effects of RU486. An obvious explanation for this apparent discrepancy is that progesterone receptors in the decidua were probably saturated with endogenous progesterone, but that RU486 could displace bound progesterone from its receptor because it has greater affinity for the receptor than progesterone itself. This could be overcome only by increasing the concentration of progesterone.

As shown previously, PAPP-A is produced by trophoblastic as well as decidual explants. PS but not serum from non-pregnant women stimulates the production of PAPP-A from both tissues (Bischof et al., 1984a). The factor which stimulates the production of PAPP-A could well be progesterone since in both tissues the secretion of PAPP-A was inhibited by RU486 and since progesterone, but not cortisol, was able to reverse these effects. These results are in good agreement with previous observations, implying indirectly that progesterone was a trigger of endometrial PAPP-A production (Bischof et al., 1982, 1984b; Sjöberg et al., 1984).

Finally, the inhibition of trophoblastic $\beta \mathrm{HCG}$ production seems to be specific since RU486 did not modify the production of HPL. This is in good agreement with the in-vivo effects of RU486. It is not clear, however, if this effect was due to a metabolite of RU486 or to the anti-gestagenic or anti-glucorticoid properties of RU486 since both progesterone and cortisol were able to overcome the effects of RU486. The trophoblastic production of HCG has long been considered as independent of any feedback mechanism. Recently, however, it was demonstrated that in long-term cultures of trophoblastic explants, progesterone inhibited the production of HCG (Wilson et al., 1984). These results are in contrast to the present observations. It remains to be determined if long-term cultures of trophoblast behave differently from shortterm cultures and if cortisol and not progesterone is the main regulator of placental HCG production.

Taken together, these results also suggest that the trophoblast of first trimester pregnancies contains an active progesterone receptor, a notion which is still controversial (Coulam and Spelsberg, 1983; Younes et al., 1981).

In conclusion, the present results tend to suggest that the abortifacient effect of RU486 in humans could at least partially be due to an inhibition of the production of HCG and/or PAPP-A.

\section{Acknowledgements}

The authors wish to thank Mrs C Gurfat and M.Mendez for their skilful assistance and Mrs D. Roiron for typing the manuscript. This work was supported by grant No. 3909.082 from the Swiss National Fund for Scientific Research.

\section{References}

Bıschof,P., Haenggeli,L., Sizonenko,M.T., Hermann, W.L. and Sizonenko,P.C. (1981), A radioimmunoassay for the measurement of pregnancy-associated plasma protein-A (PAPP-A) in humans. Biol. Reprod , 24, 1076.

Bischof,P., DuBerg,S., Schindler,A.M., Obradovich,D., Weil,A., Faigaux,R., Herrmann,W.L. and Sizonenko,P.C. (1982), Endometrial and plasma concentrations of pregnancy-associated plasma protein-A (PAPP-A). Br. J. Obstet. Gynaecol., 89, 701.

Bischof,P., DuBerg,S., Sizonenko,M.T., Schindler,A.M., Beguin,F., Herrmann, W.L. and Sizonenko,P.C. (1984a), In-vitro production of pregnancy-associated plasma protein-A (PAPP-A) by human decidua and trophoblast. Am. J. Obstet. Gynecol., 148, 13.

Bischof,P., Schindler,A.M., Umer,F., Mensi,N., Hermann,W.L. and Sizonenko, P.C. (1984b), Pregnancy-associated plasma protein-A (PAPP-A) concentration in uterine fluid and mmunohistochemical localization in the endometrium. Br. J. Obstet. Gynaecol., 91, 863.

Bischof,P., Schindler,A.M., Wyss, R., Hermann,W.L. and Sizonenko,P.C. (1985), Progesterone dependence and extratrophoblastic origin of pregnancyassociated plasma protein-A (PAPP-A) in early pregnancy. Arch. Gynecol., in press.

Coulam,C.B. and Spelsberg, T.C. (1983), The placenta as a target tissue for steroids. Troph. Res., 1, 249.

Daly,D.C., Maslar,I.A. and Rıddick,D.H. (1983), Term decıdua response to estradiol and progesterone. Am. J. Obstet. Gynecol., 145, 679.

de Ziegler,D. and Gurpide,E. (1982), Production of Prl by cultures of cells from human decidua. J. Clin. Endocrinol. Metab., 55, 511.

Gaillard,R.D., Riondel,A., Muller,M.F., Hermann,W. and Baulieu,E.E. (1984), RU486: a steroid with antiglucosteroid activity that only disinhibits the human pituitary-adrenal system at a specific time of day. Proc. Nall. Acad. Sci. USA, 81, 3879.

Healy,D.L., Baulieu,E.E. and Hodgen,G.D. (1983), Induction of menstnuation by an antiprogesterone steroid (RU486) in primates: site of action, dose-response relationships and hormonal effects. Fertil. Steril., 45, 253.

Hermann, W.L., Wyss,R., Riondel, A., Philibert,D., Teutsch,G., Sakiz,E. and Baulieu,E.E. (1982), The effect of an antiprogesterone steroid in women: interruption of the menstrual cycle and early pregnancy. C.R. Acad. Sci. (III), 294, 933.

Hermann, W.L., Schindler,A.M., Wyss,R. and Bischof,P. (1985), Effects of the antiprogesterone RU486 in early pregnancy and during the menstrual cycle. Proceedings of an Intemational Symposium on Future Apects in Contraception. 
P.Bischof, M.T.Sizonenko and W.L.Herrmann

Runnebaum,B., Rabe,T., Kiesel,L. (eds.) (1985), MTP Press Lid., pp.243-270.

Philiber, D., Deract,R., Teutsch,G., Toumemine,C. and Sakiz,E. (1982), RU486 a new lead for steroid antihormones. Program of the 64th Annual Meeting of The Endocrine Society San Francisco, California (Abstract 668).

Riddick,D.H. and Kusmik,W.F. (1977), Decidua: a possible source of amniotic fluid prolactin. Am. J. Obstet. Gynecol., 127, 187.

Sjöberg,J., Wahlstrōm,T. and Seppälä,M. (1984), Pregnancy-associated procein-A in the human endometrium is dependent on the effect of progesterone. J. Clin. Endocrinol. Metab., 58, 359.

Wilson,E.A., Jaward,M.J. and Powell,D.E. (1984), Effect of estradiol and progesterone on human chorionic gonadotropin secretion in virro. Am J. Obstet. Gynecol., 149, 143.

Younes,M.A., Besch,N.F. and Besch,P.K. (1981), Estradiol and progesterone binding in human term placental cytosol. Am. J. Obstet. Gynecol., 141, 170.

Recelved on 27 August 1985; accepted on 2 October 1985 